\title{
SOIL FERTILITY PROPERTIES, LEAF NUTRIENT STATUS AND YIELD OF COCONUT AND INTERCROPS AS INFLUENCED AND COCONUT BASED CROPPING SYSTEM IN COASTAL PLAIN OF WESTERN INDIA
}

\author{
VV SHINDE, S SUMITHA ${ }^{1} *$ AND HP MAHESWARAPPA ${ }^{1}$ \\ ICAR-AICRP on Palms, Regional Coconut Research Station, Bhatye, \\ Ratnagiri, Maharashtra-415 612
}

Keywords: Coconut, Nutrient status, Integrated, Productivity

\begin{abstract}
An experiment was conducted during 2013 -2019 to study the impact of intergrated nutrient management through organic matter recycling (OMR) on the soil properties, leaf nutrient status and yield of coconut and its components crops at Regional Coconut Research Station (AICRP on Palms), Bhatye, Maharashtra, India. The experiment was laid out in 0.40 ha with four treatments namely $T_{1}, T_{2}, T_{3}$ and $T_{4}$. Results showed that, INM practices significantly improved the soil physico-chemical, biological properties and leaf nutrient status, whereas it was more prominent for the $T_{1}$ treatment. The soil organic carbon content during post experimental period gradually increased in the organic recyclable treatment under cropping system $(0.80$ to $0.86 \%)$ compared to monocropping $(0.60 \%)$. The recyclable biomass produced from the system varied between 9.0 - $18.0 \mathrm{t} / \mathrm{ha} /$ year and vermicompost produced was 4.8 to $10.2 \mathrm{t} / \mathrm{ha} / \mathrm{year}$ by composting through earthworm. The nut yield (147.2 and 138.4 nuts/palm), copra output (25.75 and 23.06 $\mathrm{kg} / \mathrm{palm})$ and oil output $(17.11$ and $15.72 \mathrm{~kg} / \mathrm{palm})$ under treatment $\mathrm{T}_{1}$ and $\mathrm{T}_{2}$ were on par and differed significantly compared to monocrop.
\end{abstract}

\section{Introduction}

Coconut based cropping systems (CBCS) are the main agricultural production systems in plantation crops and have received priority in India in recent years. The most important challenges in soil health management are the availability of the organic manure in situ. In general, plantation crops produce large amount of biomass for recycling in the form of suitable organic manure (vermicompost) and account for more than $30-50 \%$ of the final produce (Nampoothiri 2001). Krishnakumar and Maheswarappa (2010) reported that, coconut have adequate potential to form natural farming and sustain their yield with low external input, as they produce huge quantities of biomass (leaves after removing petiole portion; spathe and bunch waste) for recycling. In this context, CBCS which involves cultivating compatible crops (Nath et al. 2008) in the interspaces of coconut offers a plenty of biomass available in situ to meet the organic matter requirement and to maintain the soil health in a very economically profitable manner and this system offers a very practical solution to the challenges of the soil health management (Malhotra et al. 2017). Subramanian et al. (2005) observed that, the highest recyclable biomass was available under $2 / 3^{\text {rd }}$ $\mathrm{RDF}$ in coconut based high density multispecies cropping system (HDMSC) at CPCRI, Kasaragod. The integrated use of organic manure and chemical fertilizers along with biofertilizers is also a promising approach in preserving soil microbial communities and activities, which will ultimately show positive impacts on different soil properties while increasing the crop productivity. Sustainability can be in built in the coconut system by introducing compatible crops as component crops and promoting positive interferences by judicious application of inputs especially fertilizers. Earlier research efforts have revealed that tree spices like nutmeg, cinnamon

*Author for correspondence: <sumithasundaram12@gmail.com>. ${ }^{1}$ ICAR- AICRP on Palms, ICAR - CPCRI, Kasaragod, Kerala-671 124. 
and fruit crops viz., banana and pineapple were compatible and economical intercrops in well spaced coconut gardens of Konkan regions (Shinde et al. 2020). With these aspects under consideration, the present investigation was conducted to assess the influence of integrated nutrient management on the soil and leaf nutrient status, microbial population and sustainability of coconut based cropping system involving coconut, banana, nutmeg, cinnamon and pineapple.

\section{Materials and Methods}

A long- term experiment was carried out in 32 years old COD x WCT coconut plantation spaced at $7.5 \times 7.5 \mathrm{~m}$ under ICAR - All India Coordinated Research Project on Palms at Regional Coconut Research Station, Bhatye (DBSKKV, Dapoli) Maharashtra, India during 2013-14 to 2018-19. The experimental site comes under the tropical humid climate, situated at $16.58^{\circ} \mathrm{N}$ latitude, and $73.17^{\circ} \mathrm{E}$ longitude at an elevation of $3.0 \mathrm{~m}$ above mean sea level with the mean minimum temperature of $21^{\circ} \mathrm{C}$ and the mean maximum temperature of $36^{\circ} \mathrm{C}$. The soil of the experimental site was red sandy loam with $6.8 \mathrm{pH}$, medium organic carbon content $(0.46 \%)$ and medium-fertility status. The average annual rainfall received is $3500 \mathrm{~mm}$, of which 82 per cent is received during the southwest monsoon (June-September). The crops in the cropping system were managed with the recommended package of practices. The details of crops grown with their mean population level over the experimental period are presented in Table 1.

Table 1. Component crops grown in coconut-based INM system.

\begin{tabular}{|c|c|c|c|c|c|}
\hline Crop & Variety & $\begin{array}{l}\text { Year of } \\
\text { planting }\end{array}$ & Spacing & $\begin{array}{l}\text { Plants/ } \\
\text { block }\end{array}$ & $\begin{array}{c}\text { Plants/ } \\
\text { ha }\end{array}$ \\
\hline Coconut & COD x WCT & 1991 & $7.5 \times 7.5 \mathrm{~m}$ & 20 & 175 \\
\hline Nutmeg & Konkan Swad & 2013 & At the center of four palms & 12 & 135 \\
\hline Cinnamon & Konkan Tej & 2014 & $2 \mathrm{~m}$ (single plant between two palms in a row) & 62 & 615 \\
\hline Banana & $\begin{array}{l}\text { Konkan } \\
\text { safedValchi }\end{array}$ & 2012 & $\begin{array}{l}2 \mathrm{~m} \text { from coconut palm in four directions and } \\
\text { between intercrops }\end{array}$ & 62 & 615 \\
\hline Pineapple & Kew & 2013 & $\begin{array}{l}\text { Paired rows of raised bed of } 45 \mathrm{~cm} \text { distance } \\
\text { between rows and } 30 \mathrm{~cm} \text { between suckers } \\
\text { (Two pair rows in between two rows of } \\
\text { coconut.) }\end{array}$ & 960 & 10800 \\
\hline
\end{tabular}

Treatment details are as follows:

$\mathrm{T}_{1}: 75$ per cent of Recommended Dose of Fertilizers (RDF) $+25 \%$ of $\mathrm{N}$ through organic recycling with vermicompost + intercrops. $\mathrm{T}_{2}: 50$ per cent of $\mathrm{RDF}+50 \%$ of $\mathrm{N}$ through organic recycling with vermicompost + Vermiwash application + bio-fertilizer application + in situ green manuring with cowpea + intercrops. $\mathrm{T}_{3}$ : Fully organic: $100 \%$ of $\mathrm{N}$ through organic recycling with vermicompost + vermiwash application + bio-fertilizer application + in situ green manuring with cowpea and green leaf manuring (Glyricidia leaves) + composted coir pith, husk incorporation (once in three years) and mulching with coconut leaves+ intercrops. $\mathrm{T}_{4}$ : Control: monocrop of coconut with recommended NPK and organic manure.

The experimental block of each treatment was laid out in 0.10 ha (1000 sq $\mathrm{m})$ coconut garden which was planted at a distance of $7.5 \mathrm{~m} \times 7.5 \mathrm{~m}$ in a square system and intercropping with released varieties of spices and fruit crops.

Recyclable biomass of coconut (leaves after removing petiole portion; spathe and bunch waste), banana (leaves and pseudostem after harvest of bunch) and nutmeg and cinnamon (pruned biomass) was collected during different years and vermicomposted in the field itself using 
Eudrilus sp. of earthworm and applied to coconut palms and component crops. The quantity of NPK and vermicompost applied under different INM practices has been described by Maheswarappa et al. (2011). As per the different INM practices, vermicompost was applied during September-October, and inorganic fertilizers in the form of urea, single super phosphate and muriate of potash were applied in three splits doses during (May-June, August-September and January- February) every year as per treatment details. The vermiwash collected was drenched in the basin of each crop by diluting it in the ratio of 1:10 with water and applied twice in the year for coconut @ 5 litres/basin, nutmeg@ 2 litres/tree, cinnamon@ 2 litres/tree banana @ 2 litres/plant, and pineapple @ 2 litres raised/bed. Cowpea was grown as green manure crop in the basins of coconut and the same was incorporated when it attained 50\% flowering stage. In addition to this, Glyricidia plants were grown as green leaf manuring crop at a border of plot and Glyricidia loppings were incorporated in the rhizosphere of coconut and intercrops in June, during application of fertilizer. Sprinkler irrigation was followed for irrigating coconut based cropping system during October to May at IW/CPE of 1.0. Husk incorporation in the trenches was followed in each set of four coconut palms. Dried coconut leaves were also used for mulching in summer months (February-May) for soil moisture conservation.

As component crops vary in their growth habit, the harvesting period also varied accordingly. The economic products were harvested as and when ready and quantified per hectare of coconut garden. The nuts were harvested periodically at maturity from July to June and pooled to get nut yield per palm per year. Copra content in a nut was recorded by drawing random sample of six nuts per treatment at each harvest, dehusking, separation of kernel from shell, drying in the shade and averaging over harvests. Copra yield per palm was computed based on the copra content in the nut in each treatment.

The soil and leaf samples were collected from three palms in each plot during preexperimental (2013-014) and post experimental (2018-19) period. Soil samples were collected from $0-25,25-50 \mathrm{~cm}$ and 50-100 $\mathrm{cm}$ depth, $1 \mathrm{~m}$ away from the bole of the coconut using augur and soil properties and microbial enumeration were determined by adopting the standard procedures. The leaf samples were collected from index leaf (14 leaf) of the coconut palm by using a specially designed knife, by cutting 4-5 leaflets from the middle of the frond on both the sides. The leaf samples were washed with distilled water, oven-dried at $65^{\circ} \mathrm{C}$ for $72 \mathrm{hrs}$ and powdered using a Tecator Cyclotec sample mill. From the powdered bulk plant samples, subsamples were weighed separately for nutrient analysis ( $\mathrm{N}, \mathrm{P}$ and $\mathrm{K}$ ), for total nitrogen analysis, 0.5 $\mathrm{g}$ was digested with $0.02 \mathrm{~N} \mathrm{H}_{2} \mathrm{SO}_{4}$ and $30 \% \mathrm{H}_{2} \mathrm{O}_{2}$ and kept for 30 min at $250^{\circ} \mathrm{C}$ temperature. Upon cooling $1 \mathrm{ml}$ of $30 \% \mathrm{H}_{2} \mathrm{O}_{2}$ added up to clearing digest and desired volume was made up with distilled water. Micro-Kjeldahl glass distillation apparatus was used to determine the total nitrogen. The digested samples were subjected to distillation and absorbed in boric acid and titrated against $\mathrm{H}_{2} \mathrm{SO}_{4}$ for $\mathrm{N}$ determination (Linder and Harley 1942). The powdered fraction (0.5 g) of leaf sample was digested in di-acid mixture of $\mathrm{HNO}_{3}: \mathrm{HClO}_{4}(3: 1)$ and analysed for phosphorus and potassium content. Phosphorus was determined by ammonium vanadomolybdo phosphoric acid yellow color method and potassium was determined by Flame photometer method (Richards 1968).

The population of bacteria, actinomycetes and fungi were determined in the collected soils by serially diluted in sterile water blanks to produce several dilutions and $1 \mathrm{ml}$ aliquot was pour plated in different media. Three sets of samples were drawn from each treatment and three replications for each group of microorganisms were maintained. Total numbers of bacteria were counted on nutrient agar after $24-48 \mathrm{hrs}$ incubation at $28^{\circ} \mathrm{C}$, actinomycetes on Ken Knights and Munaier's agar (1) counted after 5-7 incubation at $28^{\circ} \mathrm{C}$ and fungi on Martin's rose Bengal agar counted after 2-4 days incubation at $28^{\circ} \mathrm{C}$ (Allen, 1959 and Martin, 1950). The results of the 
microbial analyses were given as CFU/g of dry soil, whereas CFU value was the average of $4 \times 3$ sample replicates. Extraction of earthworm population was carried out by hand sorting of upper 20 $\mathrm{cm}$ soil with immediate formalin extraction (Rombke et al. 2006).

As the experiment was laid out in a block of 0.10 ha area for each treatment, the weather parameters during the year influence the productivity of the system. Hence, in the analysis, the year effect was taken as a fixed effect in the ANOVA table and treatment effect as error. The statistical analysis was performed using Statistical analysis system 9.3 computer software (SAS Institute Inc., 1995). DMRT procedure was used at $\mathrm{P}=0.05$ level to determine the significance among the treatments.

\section{Results and Discussion}

The recyclable biomass from coconut palm and intercrops viz., nutmeg, cinnamon, banana and pineapple under different treatments presented in Fig. 1 showed that the higher amount of recyclable biomass $(18,654 \mathrm{~kg} / \mathrm{ha} /$ year $)$ was recorded in $\mathrm{T}_{1}$ treatment followed by $\mathrm{T}_{2}$ and $\mathrm{T}_{3}$ $(17,670$ and $15,708 \mathrm{~kg} / \mathrm{ha} /$ year $)$, respectively. Total recyclable bio mass generated in the system was to the tune of $61 \mathrm{t} / \mathrm{ha}$. The increase in the biomass production in $T_{1}, T_{2}$ and $T_{3}$ treatment was due to accommodation of component crops viz., nutmeg, cinnamon, banana and pineapple. Paul et al. (2020) reported that quantity of recyclable biomass generated at arecanut garden (Assam) ranged between 8.27 to $12.23 \mathrm{t} / \mathrm{ha} /$ year. In the present studies, the total vermicompost production in the cropping system was 4.8 to 10.2 t/ha/year (Fig 1) with recovery of $52-54 \%$. Bhat and Sujatha (2007) reported that conversion of the recyclable biomass $(8,724-10,354 \mathrm{~kg} / \mathrm{ha} / \mathrm{year})$ into vermicompost in arecanut based garden with the recovery of $82-87 \%$. The present study revealed that, earthworm population in coconut basin ranged from 6.7 to 15.30 individual's $\mathrm{m}^{-2}$ at $0-10 \mathrm{~cm}$ depth and it decreased with the increase the soil depth (Fig. 2). Cropping systems thus modified specific and functional diversity as well as earthworm community biomass. It is evident that, increasing the organic matter (100\%) inputs to the soil and intercropping, promote significantly higher earthworm populations $\left(\mathrm{T}_{3}\right)$ followed by $\mathrm{T}_{1}$. On the other hand, the RDF and monocropping of coconut $\left(\mathrm{T}_{4}\right)$ recorded the lowest earthworm density $\left(6.7\right.$ individual's $\left.\mathrm{m}^{-2}\right)$. The recycling of biomass by vermicomposting and field application will reduce the chemical fertilizer requirement of coconut and cost of cultivation.

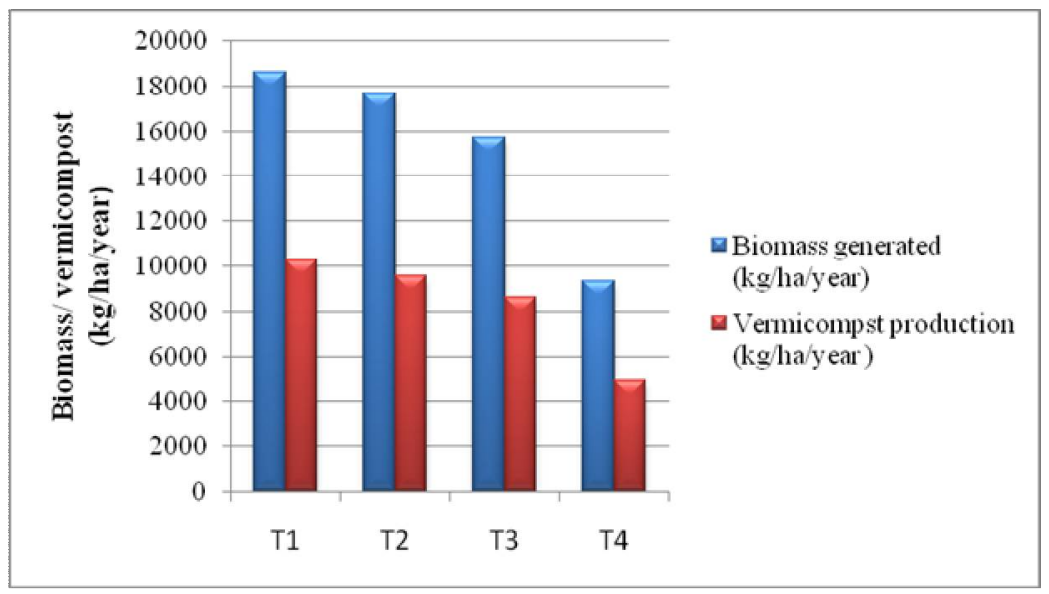

Fig. 1. Biomass generation and vermicompost production in coconut based INM system. 


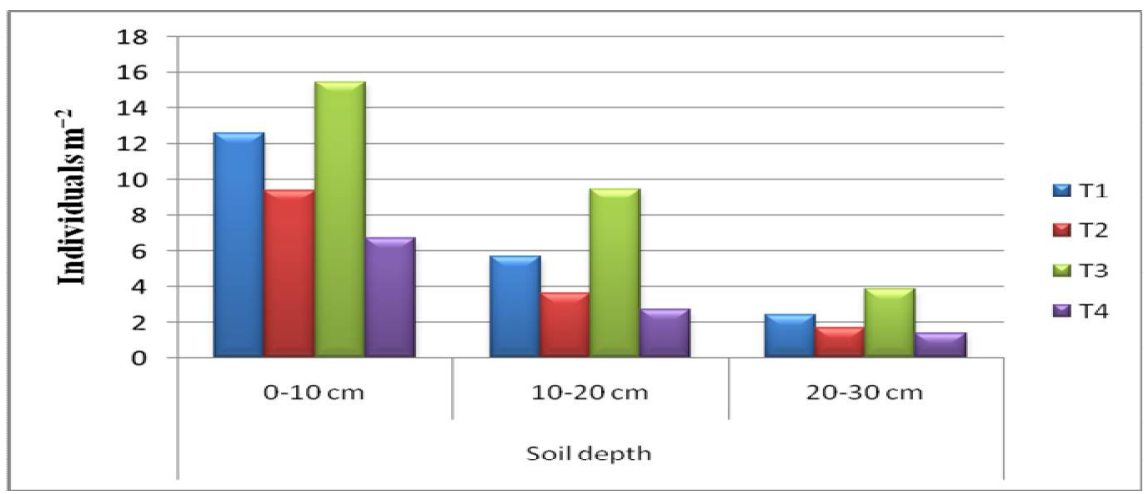

Fig. 2. Earthworm population (Individuals $\mathrm{m}^{-2}$ ) as influenced by coconut based INM system

Post-experimental soil $\mathrm{pH}, \mathrm{EC}$ and organic carbon content differed significantly among the INM treatments (Table 2). Results of soil EC revealed a significant change among INM treatments compared with the initial value. Significant increased in soil post experimental $\mathrm{pH}$ was observed with the INM treatments (7.2 to 7.5) compared with the initial soil $\mathrm{pH}$ value ( $\mathrm{pH}$ 6.8), although the numerical values of $\mathrm{pH}$ for all treatments are within the normal soil $\mathrm{pH}$ range. It also revealed that, treatment with different types of recyclable biomass either alone or in combination with $75 \%$ and $50 \%$ of the recommended NPK dose slightly increased $\mathrm{pH}$ (7.2 to 7.5$)$ compared with $\mathrm{T}_{4}(\mathrm{pH}$ 6.8). The optimum soil $\mathrm{pH}$ for coconut cultivation ranged from 6.4 to 7.0 , though the palms can also survive under soil $\mathrm{pH}$ of 7.1 to 7.5 (Issaka et al. 2012). In the present study, the post experimental soil organic content $(0.60$ to $0.86 \%)$ was observed under INM treatments compared to the initial values of 0.40 to $0.51 \%$, whereas the build-up of organic carbon was higher under

Table 2 . Effect of integrated nutrient management on soil properties and nutrient status in coconut garden at $0-25 \mathrm{~cm}$ depth.

\begin{tabular}{lccccccccc}
\hline $\begin{array}{l}\text { Treatments } \\
(0-25 \mathrm{~cm} \\
\text { depth })\end{array}$ & \multicolumn{2}{c}{$\mathrm{pH}$} & \multicolumn{2}{c}{$\mathrm{EC}(\mathrm{dS} / \mathrm{m})$} & \multicolumn{2}{c}{ OC $(\%)$} & \multicolumn{3}{c}{ Pre experimental soil NPK status } \\
\cline { 2 - 10 } & $\begin{array}{c}\text { Pre- } \\
\text { experi- } \\
\text { ment }\end{array}$ & $\begin{array}{c}\text { Post- } \\
\text { experi- } \\
\text { ment }\end{array}$ & $\begin{array}{c}\text { Pre- } \\
\text { experi- } \\
\text { ment }\end{array}$ & $\begin{array}{c}\text { Post- } \\
\text { experi- } \\
\text { ment }\end{array}$ & $\begin{array}{c}\text { Pre- } \\
\text { experi- } \\
\text { ment }\end{array}$ & $\begin{array}{c}\text { Post- } \\
\text { experi } \\
\text {-ment }\end{array}$ & $\begin{array}{c}\text { Available } \\
\text { Nitrogen } \\
(\mathrm{kg} / \mathrm{ha})\end{array}$ & $\begin{array}{c}\text { Available } \\
\text { phosphorus } \\
(\mathrm{kg} / \mathrm{ha})\end{array}$ & $\begin{array}{c}\text { Available } \\
\text { Potassium } \\
(\mathrm{kg} / \mathrm{ha})\end{array}$ \\
\hline $\mathrm{T}_{1}$ & $6.8^{\mathrm{a}}$ & $7.5^{\mathrm{a}}$ & $0.180^{\mathrm{a}}$ & $0.182^{\mathrm{b}}$ & $0.49^{\mathrm{a}}$ & $0.80^{\mathrm{c}}$ & $253^{\mathrm{b}}$ & $17^{\mathrm{b}}$ & $301^{\mathrm{a}}$ \\
$\mathrm{T}_{2}$ & $6.8^{\mathrm{a}}$ & $7.2^{\mathrm{a}}$ & $0.176^{\mathrm{a}}$ & $0.179^{\mathrm{d}}$ & $0.51^{\mathrm{a}}$ & $0.83^{\mathrm{b}}$ & $248^{\mathrm{b}}$ & $18^{\mathrm{a}}$ & $289^{\mathrm{b}}$ \\
$\mathrm{T}_{3}$ & $6.8^{\mathrm{a}}$ & $6.8^{\mathrm{b}}$ & $0.176^{\mathrm{a}}$ & $0.186^{\mathrm{c}}$ & $0.46^{\mathrm{a}}$ & $0.86^{\mathrm{a}}$ & $220^{\mathrm{c}}$ & $16^{\mathrm{c}}$ & $278^{\mathrm{b}}$ \\
$\mathrm{T}_{4}$ & $6.7^{\mathrm{a}}$ & $6.7^{\mathrm{c}}$ & $0.178^{\mathrm{a}}$ & $0.187^{\mathrm{a}}$ & $0.40^{\mathrm{a}}$ & $0.60^{\mathrm{d}}$ & $265^{\mathrm{a}}$ & $17^{\mathrm{b}}$ & $312^{\mathrm{a}}$ \\
$\mathrm{CD}(\mathrm{P}=0.05)$ & $\mathrm{NS}$ & 0.16 & $\mathrm{NS}$ & 0.004 & $\mathrm{NS}$ & 0.017 & 9.35 & 0.64 & 11.29 \\
C.V. $(\%)$ & 1.66 & 1.65 & 1.60 & 1.66 & 4.61 & 1.53 & 2.77 & 2.75 & 2.79 \\
\hline
\end{tabular}

Values followed by same lowercase letter in a column show non-significant differences at 0.05 level.

cropping system ( 0.80 to $0.86 \%$ ) compared to monocropping $\mathrm{T}_{4}(0.60 \%)$. These findings are in agreement with the earlier report from Assam by Nath et al. (2012) who observed that organic carbon increased with increasing level of $\mathrm{N}$-application in combination with vermicompost. Shinde et al. (2020) observed that, rhizosphere of intercrops like nutmeg; cinnamon, pineapple and banana also recorded higher organic carbon content, whereas, in the interspace of monocropping, it was significantly lower. Growing intercrops in the coconut garden have led to the addition of recyclable biomass from the intercrops, which has resulted in improvement in the 
organic carbon content. Similar results were also reported by Naveen Kumar et al. (2016) in coconut based cropping system with INM.

The post experimental soil nutrient status at different depths is presented in Table 3. The results indicated that, the available nitrogen was maximum $(284 \mathrm{~kg} / \mathrm{ha})$ under $\mathrm{T}_{4}$ followed by $\mathrm{T}_{1}$ and $\mathrm{T}_{2}\left(277\right.$ and $262 \mathrm{~kg} / \mathrm{ha}$ ) and the minimum was recorded under $\mathrm{T}_{3}$. The available phosphorus content of soil varied from 19.3 to $25.60 \mathrm{~kg} / \mathrm{ha}$ and differences among treatments were significant $(\mathrm{P}<.05)$. The available soil potassium content also varied from 284.0 to $318.0 \mathrm{~kg} / \mathrm{ha}$ which differed significantly among different INM treatments. Moreover, maximum soil NPK content was recorded in $\mathrm{T}_{4}$ which was due to application of recommended organic manure and straight fertilizers. Whereas under cropping system, it was observed that as the recommended NPK was reduced, the soil NPK content also found to be decreased, mainly because of the lower N and K supply through vermicompost and reduced dose of recommended N. The available NPK content in coconut rhizosphere reduced drastically at $25-50 \mathrm{~cm}$ and $50-100 \mathrm{~cm}$ soil depth.

Table 3. Soil nutrient status as influenced by the INM treatments at different soil depths (post experiment 2018-2019).

\begin{tabular}{|c|c|c|c|c|c|c|c|c|c|}
\hline \multirow{2}{*}{$\begin{array}{l}\text { Treatments } \\
\text { Depth }\end{array}$} & \multicolumn{3}{|c|}{$\begin{array}{l}\text { Available Nitrogen } \\
(\mathrm{kg} / \mathrm{ha})\end{array}$} & \multicolumn{3}{|c|}{$\begin{array}{l}\text { Available phosphorus } \\
\qquad(\mathrm{kg} / \mathrm{ha})\end{array}$} & \multicolumn{3}{|c|}{$\begin{array}{l}\text { Available Potassium } \\
\text { (kg/ha) }\end{array}$} \\
\hline & $\begin{array}{c}0-25 \\
\mathrm{~cm}\end{array}$ & $\begin{array}{c}25-50 \\
\mathrm{~cm}\end{array}$ & $\begin{array}{c}50-100 \\
\mathrm{~cm}\end{array}$ & $\begin{array}{c}0-25 \\
\mathrm{~cm}\end{array}$ & $\begin{array}{c}25-50 \\
\mathrm{~cm}\end{array}$ & $\begin{array}{c}50-100 \\
\mathrm{~cm}\end{array}$ & $\begin{array}{l}0-25 \\
\mathrm{~cm}\end{array}$ & $\begin{array}{c}25-50 \\
\mathrm{~cm}\end{array}$ & $\begin{array}{c}50-100 \\
\mathrm{~cm}\end{array}$ \\
\hline $\mathrm{T}_{1}$ & $277^{\mathrm{a}}$ & $248^{\mathrm{a}}$ & $202^{b}$ & $21.5^{\mathrm{b}}$ & $21.3^{\mathrm{a}}$ & $16.1^{\mathrm{a}}$ & $309.3^{\mathrm{ab}}$ & $286.0^{\mathrm{a}}$ & $218.3^{\mathrm{c}}$ \\
\hline $\mathrm{T}_{2}$ & $262^{\mathrm{b}}$ & $241^{\mathrm{a}}$ & $151^{\mathrm{d}}$ & $25.6^{\mathrm{a}}$ & $18.1^{\mathrm{b}}$ & $13.0^{\mathrm{b}}$ & $293.1^{\mathrm{b}}$ & $256.0^{\mathrm{c}}$ & $233.1^{\mathrm{b}}$ \\
\hline $\mathrm{T}_{3}$ & $243^{c}$ & $178^{\mathrm{b}}$ & $158^{\mathrm{c}}$ & $19.3^{\mathrm{c}}$ & $13.0^{\mathrm{d}}$ & $12.2^{\mathrm{c}}$ & $284.0^{\mathrm{c}}$ & $276.1^{\mathrm{a}}$ & $273.0^{\mathrm{a}}$ \\
\hline $\mathrm{T}_{4}$ & $284^{\mathrm{a}}$ & $251^{\mathrm{a}}$ & $221^{\mathrm{a}}$ & $20.3^{\mathrm{c}}$ & $16.0^{\mathrm{c}}$ & $13.4^{\mathrm{b}}$ & $318.0^{\mathrm{a}}$ & $278.1^{\mathrm{b}}$ & $223.1^{\mathrm{c}}$ \\
\hline $\mathrm{CD}(\mathrm{P}=0.05)$ & 6.39 & 5.64 & 4.80 & 0.44 & 0.41 & 0.32 & 7.19 & 6.48 & 5.51 \\
\hline C.V. $(\%)$ & 1.72 & 1.76 & 1.88 & 1.61 & 1.73 & 1.71 & 1.71 & 1.69 & 1.66 \\
\hline
\end{tabular}

Values followed by same lowercase letter in a column show non-significant differences at 0.05 level

Data on index leaf nutrient content (Table 4) clearly indicated that combined application of organic and inorganic biofertilizers have significantly improved the leaf nutrient content. The post experimental results indicated that, maximum leaf nitrogen and phosphorus content (1.75 and 0.18 $\%$, respectively) was recorded in $\mathrm{T}_{1}$ which was on par with $\mathrm{T}_{2}$. Almost similar trend was also observed in leaf potassium content $(1.31 \%)$ in $\mathrm{T}_{1}$. It was observed that, application of 75 and 50 $\%$ NPK along with vermicompost and biofertilizers with intercropping, the leaf NPK content also found to increase. This in turn helped the palms in increasing the leaf nutrient content which eventually influenced the reproductive behaviour of the coconut palms and ultimately reflected in the nut yield. Combined application of organic and inorganic nutrients and long term use of organics in the cropping system builds up the leaf nutrient status and nut yield was observed to be improved (Nath et al. 2012).

Table 4 showed that the soil microbial populations were highly influenced by INM treatments imposed in coconut garden under coastal plains of western India. The microbial counts in the soil represent the total microbial population in the soil, owing to better enzyme activity in relation to soil organic matter content. The improvement in microbial populations, i.e. Bacteria, fungi and actinomycetes of $95.0,153.0$ and $134.0 \mathrm{cfu} / \mathrm{g}$, respectively at $0-25 \mathrm{~cm}$ depth of soil was recorded in $T_{1}$. In the present investigation, though the top soil $(0-25 \mathrm{~cm}$ depth) is the zone of intensive microbial activity and incorporation of recyclable biomass, either alone or in conjunction with inorganic fertilizers it prompted a manifold increase in the diversity and activity of soil microbial 
population. These results revealed that, treatments received combination of intercrops, vermicompost by recycling, in situ green manuring (cowpea and Glyricidia), biofertilizer and composted coir pith had greater microbial population, which might have increased soil enzyme activity compared to chemical fertilizers application. Higher level of microbial population in the rhizosphere soils has previously been reported when treated with vermicompost and organic manures compared to inorganic fertilizers (Maheswarappa et al. 2014). Beneficial rhizosphere microflora observed in the active root zone of the different crops of the cropping system of coconut, compared to sole cropping, might have also contributed towards higher productivity.

Table 4. Leaf nutrient status (\%) and soil microbial population (cfu/g dry soil) as influenced by coconut based INM system.

\begin{tabular}{|c|c|c|c|c|c|c|c|c|c|}
\hline \multirow[t]{3}{*}{ Treatments } & \multicolumn{6}{|c|}{ Leaf nutrient status } & \multicolumn{3}{|c|}{$\begin{array}{l}\text { Soil microbial population } \\
\text { (cfu/g dry soil) (2018-19) }\end{array}$} \\
\hline & \multicolumn{3}{|c|}{$\begin{array}{l}\text { 2012-2013 (Pre- } \\
\text { experimental) }\end{array}$} & \multicolumn{3}{|c|}{$\begin{array}{l}\text { 2018-2019 (Post - } \\
\text { experimental) }\end{array}$} & \multirow[t]{2}{*}{$\begin{array}{c}\text { Bacteria } \\
\left(10^{5}\right)\end{array}$} & \multirow[t]{2}{*}{$\begin{array}{c}\text { Fungi } \\
\left(10^{4}\right)\end{array}$} & \multirow[t]{2}{*}{$\begin{array}{c}\text { Actinomycetes } \\
\left(10^{3}\right)\end{array}$} \\
\hline & $\mathrm{N}(\%)$ & $\mathrm{P}(\%)$ & $\mathrm{K}(\%)$ & $\mathrm{N}(\%)$ & $\mathrm{P}(\%)$ & $\mathrm{K}(\%)$ & & & \\
\hline $\mathrm{T}_{1}$ & $1.48^{\mathrm{a}}$ & $0.12^{\mathrm{d}}$ & $1.2^{\mathrm{a}}$ & $1.75^{\mathrm{a}}$ & $0.18^{\mathrm{a}}$ & $1.31^{\mathrm{a}}$ & $95.0^{\mathrm{a}}$ & $153.0^{\mathrm{b}}$ & $134.0^{\mathrm{b}}$ \\
\hline $\mathrm{T}_{2}$ & $1.49^{\mathrm{a}}$ & $0.14^{\mathrm{a}}$ & $1.0^{\mathrm{a}}$ & $1.71^{\mathrm{a}}$ & $0.16^{\mathrm{b}}$ & $1.26^{\mathrm{ab}}$ & $89.0^{\mathrm{b}}$ & $148.0^{\mathrm{b}}$ & $136.0^{\mathrm{a}}$ \\
\hline $\mathrm{T}_{3}$ & $1.46^{\mathrm{a}}$ & $0.13^{\mathrm{c}}$ & $0.9^{\mathrm{a}}$ & $1.53^{\mathrm{b}}$ & $0.11^{\mathrm{c}}$ & $1.24^{\mathrm{b}}$ & $77.0^{\mathrm{c}}$ & $166.0^{\mathrm{a}}$ & $112.0^{\mathrm{c}}$ \\
\hline $\mathrm{T}_{4}$ & $1.46^{\mathrm{a}}$ & $0.14^{\mathrm{b}}$ & $1.1^{\mathrm{a}}$ & $1.49^{\mathrm{c}}$ & $0.10^{\mathrm{d}}$ & $1.20^{\mathrm{c}}$ & $42.0^{\mathrm{d}}$ & $59.0^{\mathrm{c}}$ & $67.0^{\mathrm{d}}$ \\
\hline $\mathrm{CD}(\mathrm{P}=0.05)$ & NS & 0.004 & NS & 0.037 & 0.003 & 0.029 & 1.77 & 3.24 & 2.54 \\
\hline C.V. $(\%)$ & 1.68 & 1.95 & 27.48 & 1.62 & 1.67 & 1.68 & 1.67 & 1.76 & 1.62 \\
\hline
\end{tabular}

Values followed by same lowercase letter in a column show non-significant differences at 0.05 level

It is evident from the data presented in Fig. 3 that the nut yield in terms of number of nuts/tree irrespective of treatments was increased over the years (post experimental yield) than pretreatmental yield. In the present study, the average nut yield recorded over six years indicated that, it was numerically higher under $T_{1}$ treatment than the other treatments even though it was statistically on par with $T_{2}$. The mean data for nut yield were in the range of 97.2 to 147.2 nuts palm/year (2018-19). Thus, the nut yield has clearly indicated that, over the years, there was marginal increase in the yield under all the treatments compared to pre experimental yield (2012). Enhancement in coconut yield due to application of inorganic fertilizer combined with organic manure has been reported by Krishnakumar and Maheswarappa (2010). In respect of copra and oil outturn (Fig. 3) significant improvement was also observed under different INM practices, $\mathrm{T}_{1}$ registered the highest copra $(25.73 \mathrm{~kg} / \mathrm{palm})$ and oil $(17.11 \mathrm{~kg} / \mathrm{palm})$ followed by $\mathrm{T}_{2}(23.06$ and $15.72 \mathrm{~kg} / \mathrm{palm}$ ) and compared to $16.78 \mathrm{~kg} / \mathrm{palm}$ copra and $11.40 \mathrm{~kg} / \mathrm{palm}$ oil out turn in coconut monocrop.

The improvement in nut yield of the main crop by intercropping is also supported by the findings of Nath et al. (2019). The yield from component crops in terms of cinnamon bark, numbers of fruit harvested from tree in nutmeg, banana bunch weight and pineapple fruits recorded during six years of experimentation (Table 5). Though significant among the treatment, $\mathrm{T}_{1}$ was recorded the highest yield of intercrop like cinnamon bark $(17.5 \mathrm{~kg} / \mathrm{tree})$, cinnamon leaves (50 kg /tree) nutmeg fruits (47.2/tree), banana $(10.2 \mathrm{~kg} / \mathrm{bunch})$ and pineapple $(1.9 \mathrm{~kg} / \mathrm{plant})$ followed by treatment $\mathrm{T}_{2 .}$. Organic matter addition generated from each component crops acts as barrier to loss of soil and moisture in surface runoff, facilitate nutrient addition and improve the microclimate. Enhanced system productivity in coconut based cropping system with INM has 
been attributed to better growth of the crops, which was reflected in the yield of crops in the system (Shinde et al. 2020).

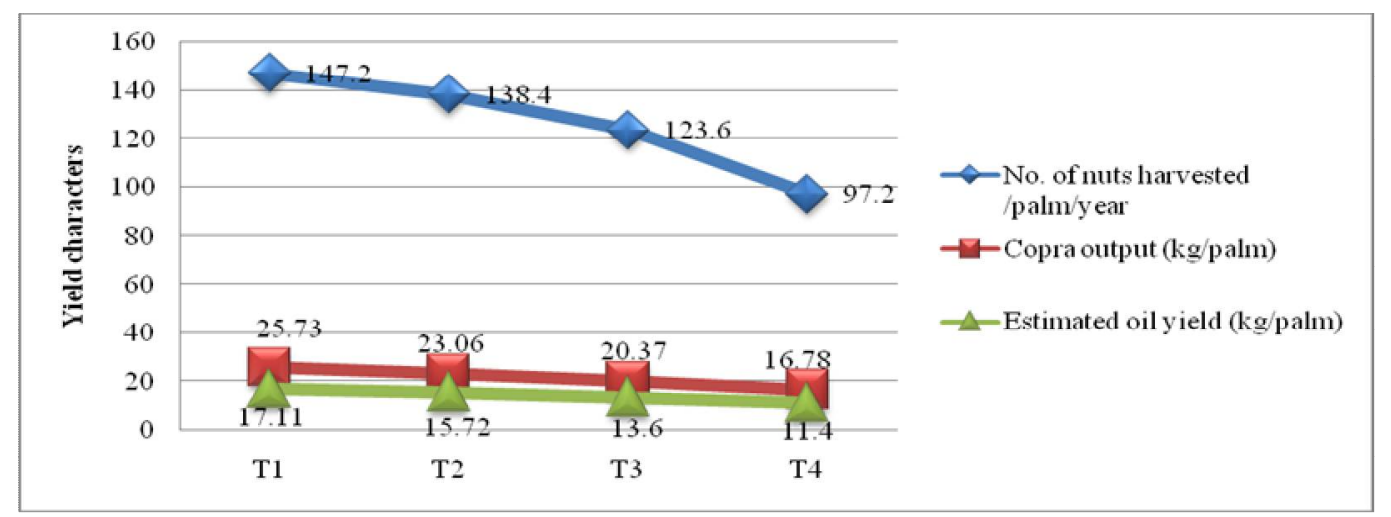

Fig. 3. Effect of coconut based INM system with respect to nut yield, copra and oil yield of coconut (pooled data $2014-15$ to $2018-19)$.

Table 5. Yield of different component crops under coconut based cropping system (Pooled data from 2016-17 to 2018-19).

\begin{tabular}{cccccc}
\hline Treatments & $\begin{array}{c}\text { Cinnamon } \\
\text { bark } \\
(\mathrm{kg} / \text { tree })\end{array}$ & $\begin{array}{c}\text { Cinnamon } \\
\text { leaves } \\
(\mathrm{kg} / \text { tree })\end{array}$ & $\begin{array}{c}\text { Nutmeg } \\
\text { (No. of } \\
\text { fruits/plant) }\end{array}$ & $\begin{array}{c}\text { Banana } \\
(\mathrm{kg} / \mathrm{bunch})\end{array}$ & $\begin{array}{c}\text { Pineapple } \\
\text { (kg/fruit) }\end{array}$ \\
\hline $\mathrm{T}_{1}$ & 17.5 & 50 & 350.8 & 10.2 & 1.9 \\
$\mathrm{~T}_{2}$ & 10.07 & 65 & 306.8 & 8.9 & 1.9 \\
$\mathrm{~T}_{3}$ & 15.4 & 57 & 275.1 & 8.1 & 1.7 \\
$\mathrm{SEm} . \pm$ & 3.83 & 7.51 & 0.32 & 0.5 & 0.058 \\
$\mathrm{CD}(\mathrm{P}=0.05)$ & 0.27 & 0.13 & 1.02 & 1.5 & 0.174 \\
\hline
\end{tabular}

From the present study, it may be concluded that integrated nutrient management by using $75 \%$ recommended fertilizer dose along with $25 \% \mathrm{~N}$ through recycling of biomass with vermicomposting $\left(T_{1}\right)$ was found worthwhile for maintaining good soil health, leaf nutrient status and yield of coconut and its component crops. The incorporation of organic compost in INM practices can help not only in substituting inorganic fertilizers totally or partially, but also in encouraging farmers to recycle different agricultural waste into a more sustainable (vermicompost), cost-beneficial and increased production and productivity unit area without affecting the ecosystem.

\section{References}

Allen ON. 1959. Experiments in Soil Bacteriology, third ed. Burgess, Minneapolis, MN, USA.

Bhat R and Sujatha S 2007. Soil fertility status as influenced by arecanut based cropping system and nutrient management. J. Plant. Crops 35(3):158-165

Issaka RN, Senayah JK, Andoh-Mensah E and Stella A. Ennin 2012. Assessment of fertility status of soils supporting coconut (Cocos nucifera) cultivation in western and central regions of Ghana. West Afr. J. Appl. Ecol. 20(1): 47 -46.

Krishnakumar V and Maheswarappa HP 2010. Integrated nutrient management for root (wilt) diseased coconut (Cocos nucifera L.) palms. Indian J. Agric. Sci. 80(5): 394-398. 
Linder RC and Harley CP 1942. A rapid method for the determination of nitrogen in plant tissue. Sci. 96: 565-66.

Maheswarappa HP, Thomas GV, Bhat R, Palaniswami C and Jayasekhar S 2011. Impact of inorganic fertilizer substitutions by vermicomposted coconut leaves on productivity and economics of coconut. J. Plant. Crops 39(1): 30-34.

Maheswarappa HP, George V Thomas, Alka Gupta, Ravi Bhat and Palaniswami C 2014. Productivity and nutrient status of coconut (Cocos nucifera) as influenced by integrated nutrient management with vermicomposted coconut leaves. Indian J. Agron. 59 (3): 455-459.

Malhotra SK, Maheswarappa HP, Selvamani V, Chowdappa P 2017. Diagnosis and management of soil fertility constraints in coconut (Cocos nucifera): A review. Indian J. Agric. Sci. 87 (6): 711-726

Martin JP. 1950. Use of acid, rose Bengal and streptomycin in the plate method for estimating soil fungi. Soil Sci. 69: 215-232.

Nampoothiri K U K. 2001. Organic Farming-Its relevance to plantation crops. J. Plant. Crops 29(1): 1-9.

Nath JC, Saud BK, Chowdhury D, Deka KK and Sarma UJ 2008. Coconut based high density multispecies cropping system in Assam. J. Plant. Crops 36(2): 98-102.

Nath JC, Arulraj S and Maheswarappa HP 2012. Integrated nutrient management in COD x WCT hybrid coconut under alluvial clay-loam soil of Assam. J. Plant. Crops 40(2): 105-110

Nath JC, Deka KK, Maheswarappa HP and Sumitha S 2019. System productivity enhancement in coconut (Cocos nucifera) garden by intercropping with flower crops in Assam. Indian J. Agric. Sci. .89 (11): 1842-1845.

Naveen Kumar KS, Maheswarappa HP and Basavaraju TB 2016. Effect of integrated nutrient management practices on growth and yield of vegetable crops grown as intercrops in coconut garden. Indian J. Agric. Sci. 86(10): 1361-1365.

Paul S, Acharya G, Chakraborty R, Maheswarappa, HP, Hussain M and Ray A 2020. Sustainability of soil health and system productivity through arecanut based cropping system in the NE Region of India. J. Plant. Crops 48(2): 111-119.

Richards LA. 1968. Diagnosis and improvement of saline and alkaline soils, 47-52. New Delhi: Hand Book No. 60, Oxford and IBH publishing Co.

Römbke J, Sousa JP, Schouten T and Riepert F 2006. Monitoring of soil organisms: a set of standardized field methods proposed by ISO. Eur. J Soil Biol. 42(1): S61-S64,

SAS Institute. 1995. SAS/STAT guide for personal computer version 6. SAS Institute, Cary, NC.

Shinde VV, Maheswarappa HP, Ghavale SL, Sumitha S, Wankhede SM and Haldankar PM 2020. Productivity and carbon sequestration potential of coconut-based cropping system as influenced by integrated nutrient management practices. J. Plant. Crops 48(2): 103-111.

Subramanian P, Srinivasa Reddy DV, Palaniswami C, Gopalasundaram P and Upadhyay AK 2005. Studies on nutrient export and extent of nutrient recycling in coconut based high density multispecies cropping. CORD 21(1): 20-27. 